\title{
Radiolysis of Aqueous Solutions of Ammonium Bicarbonate over a Large Dose Range
}

Draganic, Z.D.; Draganic, I.G.; Negron-Mendoza, A.; Sehested, Knud; Navarro-Gonzales, R.; AlbarranSanchez, M.G.

\section{Publication date:}

1987

Document Version

Publisher's PDF, also known as Version of record

Link back to DTU Orbit

Citation (APA):

Draganic, Z. D., Draganic, I. G., Negron-Mendoza, A., Sehested, K., Navarro-Gonzales, R., \& Albarran-Sanchez, M. G. (1987). Radiolysis of Aqueous Solutions of Ammonium Bicarbonate over a Large Dose Range. Risø National Laboratory. Risø-M No. 2621

\section{General rights}

Copyright and moral rights for the publications made accessible in the public portal are retained by the authors and/or other copyright owners and it is a condition of accessing publications that users recognise and abide by the legal requirements associated with these rights.

- Users may download and print one copy of any publication from the public portal for the purpose of private study or research.

- You may not further distribute the material or use it for any profit-making activity or commercial gain

- You may freely distribute the URL identifying the publication in the public portal 
Radiolysis of Aqueous Solutions
of Ammonium Bicarbonate
over a Large Dose Range
z. D. Draganic, I. G. Draganic, A. Negrón-Mendoza, K. Sehested, R. Navarro-Gonzales and M. G. Albarrán-Sánchez

Riso National Laboratory, DK-400o Roskilde, Denmark December 1986 
Rise-M-2621

RADIOLYSIS OF AQUEOUS SOLUTIONS OF AMMONIUM BICARBONATE OVER A LARGE DOSE RANGE

2.D. Draganićk, I.G. Draganick*, A. !legrón-Mendoza**, K. Sehested, R. NavarroConźales $^{* *}$ and M.L. Albarrán-Sánchez**

* Boris Kidrić Institute of Nuclear Sciences, F.0. Box 522, 11001 Belgrad, Yugoslavia

* Centro de Estudios Nucleares, Universidad Nacional Autonoma de Mexico, A. Postal 70-543, o4510 Mexico, D.F., Mexico.

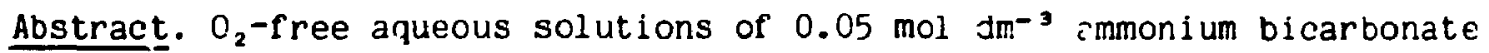
were stujied after receiving various doses of ${ }^{\circ}{ }^{\circ} \mathrm{Co}$ gammas $(0.001-170 \mathrm{Mrd})$ or krd pulses of $10 \mathrm{MeV}$ electrons. Formate, oxalate, formaldehyde and an uniden-

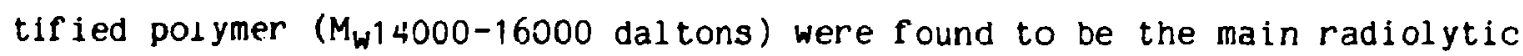
products. A large initial yieid of formate in the $\gamma$-radiolysis, $G\left(\mathrm{HCOO}^{-}\right)=$ 2.2 , is due to the reaction $\mathrm{CO}_{2}^{-}+\mathrm{HCO}_{3}^{-}+\mathrm{HCOO}^{-}+\mathrm{CO}_{3}^{-}$. The efficiency of organic synthesis within the large dose range studied is low and is explained by efficient pathways to the reformation of blcarbonate, where the reaction $\mathrm{CO}_{2}^{-}+\mathrm{CO}_{3}^{-}$is particularly significant. Computer fitting of the data obtained in the $\gamma$-radiolysis and by pulsed electron beam experiments gives $\mathrm{k}_{\left(\mathrm{CO}_{2}^{-}\right.}+$ $\left.\mathrm{HCO}_{3}^{-}\right)=(2 \pm 0.4) \times 10^{3} \mathrm{dm}^{3} \mathrm{~mol}^{-1} \mathrm{~s}^{-1}, \mathrm{k}\left(\mathrm{CO}_{2}^{-}+\mathrm{Cu}_{3}^{-}\right)=(5 \pm 1) \times 10^{7} \mathrm{cin}^{3} \mathrm{~mol}^{-1} \mathrm{~s}^{-1}$, $k\left(\mathrm{NH}_{2}+\mathrm{HCO}_{3}^{-}\right)<10^{4} \mathrm{dm}^{3} \mathrm{~mol}^{-1} \mathrm{~s}^{-1}$ and $k\left(\mathrm{NH}_{2}+\mathrm{CO}_{3}^{-}\right)=(1.5 \pm 0.5) \times 10^{9}$ $\mathrm{dm}^{3} \mathrm{~mol}^{-1} \mathrm{~s}^{-1}$.

Risø National Laboratory, DK 4000 Roskilde, Denmark December 1905 
ISBN $87-550-1288-4$ ISSN 0418-6435

Graphic Services, Risø 1986 
CONTENTS

1. INTRODUCTION $\ldots \ldots \ldots \ldots \ldots \ldots \ldots \ldots \ldots \ldots \ldots \ldots \ldots \ldots \ldots \ldots \ldots \ldots \ldots \ldots \ldots \ldots \ldots . \ldots$

2. EXPERIMENTAL $\ldots \ldots \ldots \ldots \ldots \ldots \ldots \ldots \ldots \ldots \ldots \ldots \ldots \ldots \ldots \ldots \ldots \ldots \ldots \ldots \ldots \ldots . \ldots . \ldots \ldots$

2.1 Samples $\ldots \ldots \ldots \ldots \ldots \ldots \ldots \ldots \ldots \ldots \ldots \ldots \ldots \ldots \ldots \ldots \ldots \ldots \ldots \ldots$

2.2 Irradiation $\ldots \ldots \ldots \ldots \ldots \ldots \ldots \ldots \ldots \ldots \ldots \ldots \ldots \ldots \ldots \ldots \ldots \ldots$

2.3 Analyses $\ldots \ldots \ldots \ldots \ldots \ldots \ldots \ldots \ldots \ldots \ldots \ldots \ldots \ldots \ldots \ldots \ldots \ldots \ldots \ldots \ldots$

3. COMPUTER SIMULATION $\ldots \ldots \ldots \ldots \ldots \ldots \ldots \ldots \ldots \ldots \ldots \ldots \ldots \ldots \ldots \ldots \ldots \ldots \ldots \ldots . \ldots$

4. RESULTS AND DISCUSSION ............................ 8

4.1 General $\ldots \ldots \ldots \ldots \ldots \ldots \ldots \ldots \ldots \ldots \ldots \ldots \ldots \ldots \ldots \ldots \ldots \ldots$

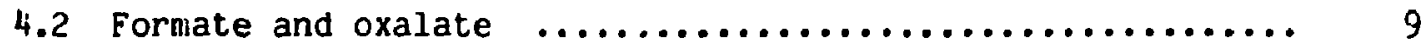

4.3 Formaldehyde $\ldots \ldots \ldots \ldots \ldots \ldots \ldots \ldots \ldots \ldots \ldots \ldots \ldots \ldots \ldots \ldots \ldots \ldots \ldots . . \ldots \ldots$

4.4 Polymeric material $\ldots \ldots \ldots \ldots \ldots \ldots \ldots \ldots \ldots \ldots \ldots \ldots \ldots \ldots \ldots \ldots \ldots$

4.5 Influence of $\mathrm{pH}$ and absorbed dose $\ldots \ldots \ldots \ldots \ldots \ldots \ldots \ldots \ldots$

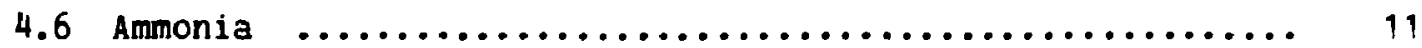

4.7 Carbanate $\ldots \ldots \ldots \ldots \ldots \ldots \ldots \ldots \ldots \ldots \ldots \ldots \ldots \ldots \ldots \ldots \ldots \ldots \ldots \ldots \ldots$

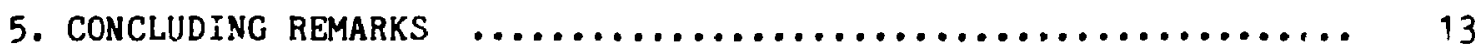

Figure

References 


\section{INTRODUCTION}

Bicarbonate was examined as the carbon source for radiation-induced synthesis of simple organic compounds in experiments relevant to economic fixation of carbon $(1,2)$ or to the origin of biclogically significant compounds on the primitive earth(3). The data presently available are not sufficient to explain the radiolytic behaviour of the bicarborate solutions in spite of the well-established behaviour of the carbonate radical-ion $(4,5,6)$. Such an understanding is needed, however, also in studies where bicarbonate is not initially present in the system but does accumulate with dose as a result of decomposition of its constituents. In some cases $(7,8)$ the ancumulated bicarbonate may become even cne of the dominant constituents at advanced stages of radiolysis.

\section{EXPERIMENTAL}

\subsection{Samples}

The syringe technique and bubbling w:th argon were used in preparing fresh, $\mathrm{O}_{2}$-free, samples...r each irradiation. When larger amounts of the sample were needed for ana:ysis a Pyrex vessel $(450 \mathrm{ml}$ ) was used. The vessel was provided with a cap that permitted radiolytically produced $\mathrm{H}_{2}$ at larger doses to diffuse out gradually to avoid build-up of an overpressure above the liquid, and to prevent air from entering the solution. Ammonium bicarbonate, sodium bicarbonate, ammonium carbonate and ammonium carbamate were Merck products (highest purity available).

\subsection{Irradiation}

\footnotetext{
${ }^{\circ} \mathrm{Co}$ gammas at a dose rate of $1.3 \mathrm{Mrd} \mathrm{h}^{-1}$ were delivered in a $50 \mathrm{kCi}$ (nominal) irradiation unit at CEN-UNAM (Mexico), at sample temperatures up to $40^{\circ} \mathrm{C}$.
} 
In pulser electron beam experiments the 10-MeV HRC accelerator at Rise was used with a pulse width of 0.2 us and a dose of 0.05-2.0 krd. The optical cetec. system consists of a 150-W Varian high-pressure xenon lamp and a Perkin Elmer double quartz prism monochromator with a 1P?8 photomultipjier. The lata were recorded on a Nicolet Explorer III digital storage oscilloscope and itored on disks. The data treatment was performed by using an on-line FDP-8 computer.

\subsection{Analyses}

Reuction of $\mathrm{Ce}^{4+}$ in acid medium was used for the determination of formic acid. All simple organir. compounds apart from formic acid are oxidized in $4 \mathrm{M}$ per..iloric acid. The difference of ceric ion concentrations in $\mathrm{H}_{2} \mathrm{SO}_{4}$ (concentrated) and $\mathrm{HClO}_{4}(4 \mathrm{M})$ was obtained from spectrophotometric measurements at $320 \mathrm{~nm}$ and used in calcula'ing of the $\mathrm{HCOOH}$ concentration. Low concentrations of $\mathrm{H}_{2} \mathrm{O}_{2}$ do not affect the finding $\mathrm{Cn}$ formic acid under our conditions. Some complenentiry ineasurements were also made with chromotropic acid.

A searsh for aldehydes, carboxylic acids, hydrazine and hydroxylamine was made by introducing an aliquot irradiated sample directly into the gas chrcmatograph, a Varian Aerograph 2400 instrument with a Hewlett-Packard integrato: terminal 3388A and a flame ionization detector; the stainless steel column was packed with the chromosorb 102. During a run the temperaturs rose from $60^{\circ} \mathrm{C}$ to $230^{\circ} \mathrm{C}$ at increments of $6^{\circ} \mathrm{C} \mathrm{min}^{-1}$. The detection limits were $10^{-6} \mathrm{~mol}^{-3} \mathrm{~m}^{-3}$ or lower(9).

Another search for aldehydes and keto acids was made after the separation with 2,4-dinitrophenylhydrazine: it was performed by paper chromatography or a subsequent esterification and gas chromatcgraphy.

Formaldehyde was measured oy spectrophotometry with 2,4 dinitropherylhydra$z$ ine at $\lambda=43 z \mathrm{rm}$ and $\varepsilon 432=14667 \mathrm{~mol}^{-1} \mathrm{~cm}^{-1}$. The method was considered satisfactory 3 ince the search for aldehydes and keto acids has shown only the presence of formaldehyde.

The nonvolatile radiolytic products were concentrated by evaporating the irradiated solutijon at reduced pressure and $45^{\circ} \mathrm{C}$; the undecomposed bicambonate was eliminatol by subsequent, heating at $50^{\circ} \mathrm{C}$ for $20-30$ minutes. 
Oxalic acid was determined by gas chromatography from the try residue by using a procedure for esterification and separation given elsewhere $(10)$.

A search for glycine was made by spectrophotometry witr. ninhydrin or by gas chromatography of volatile derivatives.

A molecular weight determination was made with a HPLC (Varian 5000) on the Micro Pak TKS Gel $2000 \mathrm{SW}$ column $(30 \times 0.75 \mathrm{~cm})$, using sodium phosphate buffer (pH 7) as eluent (8).

Routine KBR technique and a Perkin Elmer 5998 instrument were used for recording the IR spectra. Blanks were treated in the same way as the irradiated samples.

\section{COMPITER SIMULATION}

The reaction mechanism and the formation of products were analysed by computer simulation using the CHEMSIMUL program $(10)$ on a Burroughs $7800 \mathrm{com}-$ puter.

The following main bimolecular reactions of primary water radicals were included in the reaction scheme which usually consisted of about one hundred reactions:

$$
\begin{aligned}
& e_{\mathrm{aq}}^{-}+\mathrm{OH}+\mathrm{OH}^{-} \\
& k_{1}=2.5 \times 10^{10} \mathrm{dm}^{3} \mathrm{~mol}^{-1} \mathrm{~s}^{-1} \\
& \mathrm{e}_{\mathrm{aq}}^{-}+\mathrm{H}_{2}^{\mathrm{H}_{2} \mathrm{O}} \mathrm{H}_{2}+\mathrm{OH}^{-} \\
& k_{2}=2 \times 10^{20} \mathrm{dm}^{3} \mathrm{~mol}^{-1} \mathrm{~s}^{-1} \\
& e_{a}^{-} q+e_{\bar{a} q}^{-2 \mathrm{H}_{z}{ }^{O}} \mathrm{H}_{2}+2 \mathrm{OH}^{-} \\
& k_{3}=3 \times 10^{9} \mathrm{dm}^{3} \mathrm{~mol}^{-1} \mathrm{~s}^{-1} \\
& e_{a q}^{-}+\mathrm{H}_{2} \mathrm{O}_{2}+\mathrm{OH}^{-}+\mathrm{OH} \\
& k_{4}=1.6 \times 10^{10} \mathrm{dm}^{3} \mathrm{~mol}^{-1} \mathrm{~s}^{-1} \\
& \mathrm{OH}+\mathrm{OH}+\mathrm{H}_{2} \mathrm{O}_{2} \\
& \mathrm{k}_{3}=6 \times 10^{9} \mathrm{dm}^{3} \mathrm{~mol}^{-1} \mathrm{~s}^{-1}
\end{aligned}
$$




$$
\begin{array}{ll}
\mathrm{OH}+\mathrm{H} \rightarrow \mathrm{H}_{2} \mathrm{O} & \mathrm{k}_{6}=2.5 \times 10^{10} \mathrm{dm}^{3} \mathrm{~mol}^{-1} \mathrm{~s}^{-1}(6) \\
\mathrm{H}+\mathrm{H} \rightarrow \mathrm{H}_{2} & \mathrm{~K}_{7}=1 \times 10^{10} \mathrm{dm}^{3} \mathrm{~mol}^{-1} \mathrm{~s}^{-1}
\end{array}
$$

If not otherwise stated, the rate constants are taken from refs. 11 and 12 . The values of $\mathrm{G}_{e_{a q}^{-}}, \mathrm{G}_{\mathrm{H}}$ and $\mathrm{G}_{\mathrm{OH}}$ were taken from ref. 13 .

4. RESULTS AND DISCUSSION

\subsection{General}

Throughout the dose-range used the radiolytic products were formate and oxalate and an unidentified polymer $\left(M_{W} 14000-16000\right.$ daltons) (FIB. 1), besides $H_{2}$ from water decomposition and trace amounts of formaldehyde and $\mathrm{H}_{2} \mathrm{O}_{2}$. $A$ search for other products like $\mathrm{CO},(\mathrm{CHC})_{2}, \mathrm{CH}_{3} \mathrm{CHO}, \mathrm{CHOCO}_{2}^{-}, \mathrm{NH}_{2} \mathrm{NH}_{2}, \mathrm{NH}_{2} \mathrm{OH}$ and $\mathrm{NH}_{2} \mathrm{CH}_{2} \mathrm{CO}_{2}^{-}$gave negative answers with methods which had detection limits of $10^{-6} \mathrm{~mol} \mathrm{dm}^{-3}$ or lower.

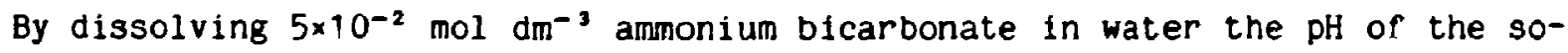
lutions becomes 7.8. Besides the bicarbonate ion, the solution contains equilibrium concentrations of carbon dioxide and carbonate:

$$
\mathrm{CO}_{2} \underset{\mathrm{pK}_{1}}{\stackrel{\mathrm{H}_{2} \mathrm{O}}{\rightleftarrows}} \mathrm{HCO}_{3}^{-}+\underset{\mathrm{HK}_{2}^{+}}{\stackrel{+}{t}} \mathrm{CO}_{3}^{2-}+2 \mathrm{H}^{+}, \mathrm{pK}_{1}=6.46 \text { and } \mathrm{pK}_{2}=10.30
$$

Because of the presence of ammonia, one has also to consider the equilibrium

$$
\mathrm{NH}_{4}^{+} \underset{\mathrm{pK}}{\rightleftarrows} \mathrm{NH}_{3}+\mathrm{H}^{+}, \quad \mathrm{pK}_{3}=9.24
$$

When the $\mathrm{pH}$ effect was examined ( $\mathrm{pH}$ between 6 and 12), ammonia, sodium hydroxide, and ammonium or sodium carbonate were used. The solutions contained also some carbamate in equilibrium with carbonate when prepared from ammonlum carbonate, but only micromol amounts since the equilibrium in dilute solutions shifts strongly tuwards bicarbonate(14). 
Reactions of the solutes used in this work with the primary radinals in water are well established; the following reactions are significant under our working conditions:

$$
\begin{aligned}
& \mathrm{CO}_{2}+e_{\mathrm{aq}}^{-}+\mathrm{CO}_{2}^{-} \quad \mathrm{k}_{0}=8 \times 10^{9} \mathrm{dm}^{3} \mathrm{mcl}^{-1} \mathrm{~s}^{-1} \\
& \mathrm{HCO}_{3}^{-}+\mathrm{OH} \rightarrow \mathrm{CO}_{3}^{-}+\mathrm{H}_{2} \mathrm{O} \quad \mathrm{k}_{9}=1.5 \times 10^{7} \mathrm{dm}^{3} \mathrm{~mol}^{-1} \mathrm{~s}^{-1} \\
& \mathrm{CO}_{3}^{2-}+\mathrm{OH} \rightarrow \mathrm{CO}_{3}^{-}+\mathrm{OH}^{-} \quad \mathrm{k}_{10}=3 \times 10^{\circ} \mathrm{dm}^{3} \mathrm{~mol}^{-1} \mathrm{~s}^{-1} \\
& \mathrm{NH}_{3}+\mathrm{OH} \rightarrow \mathrm{NH}_{2}+\mathrm{H}_{2} \mathrm{O} \quad \mathrm{k}_{11}=1 \times 10^{6} \mathrm{dm}^{3} \mathrm{~mol}^{-1} \mathrm{~s}^{-1} \\
& \mathrm{NH}_{4}^{+}+e_{\mathrm{aq}}^{-}+\mathrm{H}+\mathrm{NH}_{3} \quad k_{12}=2 \times 10^{6} \mathrm{dm}^{3} \mathrm{~mol}^{-1} \mathrm{~s}^{-1}
\end{aligned}
$$

\subsection{Formate and oxalate}

The formation of formate (Fig. 1A) occurs in a large initial yield, $\mathrm{G}^{\circ}\left(\mathrm{HCOO}^{-}\right.$) $=2.2$, while that of oxalate (Fig. 1B), $\mathrm{G}^{\circ}\left(\mathrm{C}_{2} \mathrm{O}_{4}^{2-}\right)=0.05$, is lower than expected from the known reactions of carbo $:$ radical-ion $\mathrm{CO}_{2}^{-}$

$$
\begin{array}{ll}
\mathrm{CO}_{2}^{-}+\mathrm{CO}_{2}^{-} \rightarrow \mathrm{C}_{2} \mathrm{O}_{4}^{2-} & \mathrm{k}_{14}=4 \times 10^{\circ} \mathrm{dm}^{3} \mathrm{moi}^{-1} \mathrm{~s}^{-1} \\
\mathrm{CO}_{2}^{-}+\mathrm{H}_{2} \mathrm{O}_{2} \rightarrow \mathrm{CO}_{2}+\mathrm{OH}^{-}+\mathrm{OH} & \mathrm{k}_{13}=7 \times 10^{5} \mathrm{dm}^{3} \mathrm{~mol}^{-1} \mathrm{~s}^{-1}(15,16)
\end{array}
$$

Therefore we have examined the kinetic behavior of the $\mathrm{CO}_{2}^{-}$radical ion in aqueous $\left(\mathrm{O}_{2}\right.$-free) solutions containing various concentrations of sodium $\mathrm{ki}$ carbonate $\left(0.025-1 \mathrm{~mol} \mathrm{dm}^{-3}\right)$. The bimolecular second order decay of $\mathrm{CO}_{2}^{-}$ (reaction (13)) measured at $\lambda=250 \mathrm{~nm}$ is dominant in dilute solutions at larger doses per pulse, and the second-order rate constant is in agreement wilh literature values(16). This supports the larger yields of oxalate (G= 0.4-1.7) which were reported in the earlier work(1) with 2-MeV electrnns, where $0.1-1 \%$ solutions of ammonium, sodium or calcium bicarbonate were irradiated. However, at 10 doses per pulse (50 rd) and larger concentrations of bicarbonate $\left(0.5^{-1} \mathrm{~mol} \mathrm{\textrm {dm } ^ { - 2 } )}\right.$ mixed kinetics of the $\mathrm{CO}_{2}^{-}$radical-ion decay are observed. The presence of a pseudo-first-order process at the end of the decay indicates a reaction of the carboxyl radical-ion with the solute. 


$$
\mathrm{CO}_{2}^{-}+\mathrm{HCO}_{3}^{-} \rightarrow \mathrm{HCOO}^{-}+\mathrm{CO}_{3}^{-} \quad \mathrm{k}_{15}=2 \times 10^{3} \mathrm{dm}^{3} \mathrm{~mol}^{-1} \mathrm{~s}^{-1}
$$

A minor loss of carboxyl radicals is attributed to the cross reaction between the $\mathrm{CO}_{2}^{-}$and $\mathrm{CO}_{3}^{-}$

$$
\mathrm{CO}_{2}^{-}+\mathrm{CO}_{3}^{-} \rightarrow \mathrm{CO}_{2}+\mathrm{CO}_{3}^{2-} \quad \mathrm{k}_{16}=5 \times 10^{7} \mathrm{dm}^{3} \mathrm{~mol}^{-1} \mathrm{~s}^{-1}
$$

The values $k_{15}$ and $k_{16}$ were derived by computer fitting of the experimental data on the initial yields of formate and oxalate in r-radiolysis, and on the dependence of transient absorbancy on the dose per pulse and the bicarbonate concentrations (up to $1 \mathrm{M}$ ). The reaction scheme also include the following reactions:

$$
\begin{array}{ll}
\mathrm{CO}_{3}^{-}+\mathrm{CO}_{3}^{-}+\mathrm{CO}_{2}+\mathrm{CO}_{4}^{2-} & \mathrm{k}_{17}=1 \times 10^{7} \mathrm{dm}^{3} \mathrm{~mol}^{-1} \mathrm{~s}^{-1}(6) \\
\mathrm{CO}_{4}^{2-} \mathrm{H}_{3} \mathrm{O}_{2}+\mathrm{HO}_{2}^{-}+\mathrm{OH}^{-} & \left.\mathrm{k}_{1 \mathrm{O}}=10 \mathrm{~s}^{-1}: 6\right) \\
\mathrm{CO}_{3}^{-}+\mathrm{H}_{2} \mathrm{O}_{2}\left(\mathrm{HO}_{2}^{-}\right) \rightarrow \mathrm{HCO}_{3}^{-}+\mathrm{HO}_{2}\left(\mathrm{O}_{2}^{-}\right) & \mathrm{k}_{2} \mathrm{O}_{2}=4.3 \times 10^{3} \mathrm{dm}^{3} \mathrm{~mol}^{-1} \mathrm{~s}^{-1}(6) \\
\mathrm{k}_{2}^{-}=3.0 \times 10^{7} \mathrm{dm}^{3} \mathrm{~mol}^{-1} \mathrm{~s}^{-1} \\
\mathrm{CO}_{3}^{-}+\mathrm{HCOO}^{-}+\mathrm{HCO}_{3}^{-}+\mathrm{CO}_{2}^{-} & \mathrm{k}_{2 \mathrm{O}}=1.5 \times 10^{5} \mathrm{dm}^{3} \mathrm{~mol}^{-1} \mathrm{~s}^{-1}
\end{array}
$$

A comparison of calculated and measured data suggests that the eqs. $(1-20)$ given above, as well as those relevant to ammonia (eqs. 21-23), can account for the formation yields of formate and oxalate. The formation of oxalate by reaction (13) occurs in competition with reactions (14)-(16). The reactions (15) and (20) are equilibrium reactions. These are efficient only at low jose rates and larger bicarbonate concentrations and explain the high initial yield of formate in r-radiolysi3. As a consequence, the recombination of carboxyl radical-ions (eq. 13) decreases and explains the low yields of oxalate found presently with ${ }^{\circ} \mathrm{Co}$ gamma rays, and previously(2) with suspensions of various metal carbonates which were irradiated with $70 \mathrm{keV}$ X-rays or gammas from radioactive cobalt.

At larger doses the formate and oxalate appear in low steady-state concentra-

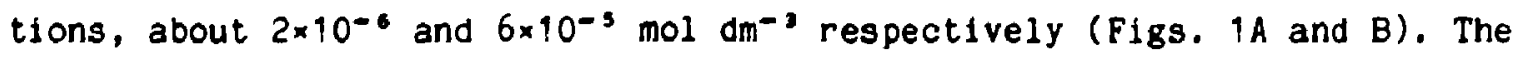
accumulation of primary and secondary radinlytic products, particularly formaldehyde and polymeric material, complicates the reaction scheme, and computer simulations cannot be done with existing experimental data. 


\subsection{Formaldehyde}

Formaldehyde is present in concentrations lower by one order of magnitude than formic ucid. The steady-state concentration $\left(2 \times 10^{-7} \mathrm{~mol} \mathrm{dm}^{-3}\right)$ starts after about $5 \mathrm{krd}$, and the dosage curve suggests that it is a secondary product from the radiolytic decomposition of formate.

\subsection{Polymeric material}

The dosage curve in Fig. $1 \mathrm{C}$ shows that the polymer is also a secondary radiolytic product. Its total mass is low and at $170 \mathrm{Mrd}$ accounts for about 37 of the mass of bicarbonate initially present. The HPLC measurements give only one large peak which increases with dose and corresponds to $M_{W} ! 4000-$ 16000 daltons. The infrared spectra consists mainly of broad bands which are common for polymeric material and difficult to assign; they show clearly that nitrogen is absent. Some other observations on acid hydrolysis and the dependence of temperature range on softening and melting suggest that it may be a composite material. More work is needed for its characterlzation.

\subsection{Influence of $\mathrm{pH}$ and absorbed dose}

At $\mathrm{pH}>10$ the corcentrations of all radiolytic products decrease in a micner that is similar to the trend shown in the insert of Fig. 1B where the data for oxalate are given. It is worth noting also that the irradiations at large dose rates did not produce oxalic acid in carbonate solutions at $\mathrm{pH}>10(1)$. This supports the present findings that the origin of formate and oxalate, and consequently of the secondary radiolytic products (formaldehyde and polymer) is in the reaction of the hydrated electron :: th carbon dioxide, which is present in the solution in equilibrium with the bicarbonate; at $\mathrm{pH}>10$ this equilibrium is shifted towards $\mathrm{CO}_{3}^{2-}$, and the absence of $\mathrm{CO}_{2}$ explains the absence of organic compounds.

\subsection{Ammonia}

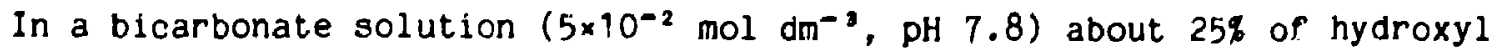
radicals disappear by reaction (11) producing $\mathrm{NH}_{2}$ radicals. Our kinetic-spec- 
trophotometric experiments suggest that the fate of the $\mathrm{NH}_{2}$ radical is

$$
\mathrm{NH}_{2}+\mathrm{CO}_{3}^{-} \rightarrow \mathrm{NH}_{2} \mathrm{O}^{-}+\mathrm{CO}_{2}
$$

and a rate constant of $(1.5 \pm 0.5) \times 10^{9} \mathrm{dm}^{3} \mathrm{~mol}^{-1} \mathrm{~s}^{-1}$ is derived from the disappearance of $\mathrm{CO}_{3}^{-}$, which was observed at $600 \mathrm{~nm}$ in experiments where the reactivity of hydroxyl radicals towards $\mathrm{NH}_{3}$ and $\mathrm{HCO}_{3}^{-}$were equal. Similar reactions of carbonate radical-ion by 0 -transfer were examined elsewhere (17). The experiments also suggest the reaction

$$
\mathrm{NH}_{2}+\mathrm{HCO}_{3}^{-} \rightarrow \mathrm{NH}_{3}+\mathrm{CO}_{3}^{-}
$$

similar to that of $\mathrm{CO}_{2}^{-}$(eq. 15), but with $\mathrm{k}_{22}<10^{4} \mathrm{dm}^{3} \mathrm{~mol}^{-1} \mathrm{~s}^{-1}$. Other known reactions $(18)$ might also account for the disappearance of $\mathrm{NH}_{2}, \mathrm{e} \cdot \mathrm{g}$.

$$
\mathrm{NH}_{2}+\mathrm{NH}_{2}+\mathrm{N}_{2} \mathrm{H}_{4} \quad \mathrm{k}_{23}=2.2 \times 10^{9} \mathrm{dm}^{3} \mathrm{~mol}^{-1} \mathrm{~s}^{-1}
$$

or the reaction with hydrogen peroxide, $\mathrm{k}\left(\mathrm{NH}_{2}+\mathrm{H}_{2} \mathrm{O}_{2}\right)=9 \times 10^{7} \mathrm{dm}^{3} \mathrm{~mol}^{-1} \mathrm{~s}^{-1}$. Nevertheless, the reaction (22) is the mosit likely fate of the $\mathrm{NH}_{2}$ radical in $\gamma$-radiolysis, because of the very low concentrations of radicals in the irradiated solution. Hydroxylamine and hydrazine, if formed at all, decompose by forming ammonia and nitrogen as main radiolytic products, and nitrogen is not found in the organic radiolytic products or in the polymer.

\subsection{Carbamate}

Cartamate is present in ammonium carbonate solutions in equilibrium concentrations which depend on the total ammonium carbonate-carbamate concentration(14). We have made pulsed electron beam experiments with 0.05 and 0.25 mol $\mathrm{dm}^{-3}$ solutions ( $\mathrm{pH} 9.0$ and 10.4 ) where the equilibrium concentrations of carbamate were estimated to be $7 \%$ and $50 \%$ respectively. In all samples, both argon or $\mathrm{N}_{2} \mathrm{O}$ saturated; we found only the $\mathrm{CO}_{3}^{-}$radical in amounts which are expected if only reactions (9)-(11) czcur. We have concluded that under the working conditions either the carbamate takes no part in the reaction process or its reactions lead to the carbonate radical-ion, 1.e. the same product as in the radiolysis of carbonate. 
5. CONCLUDING REMARK

Radiation chemical reactivity of the bicarbonate ion is limited to its reaction with $\mathrm{OH}$ (eq. 9) which is followed by reactions leading efficiently to the re-fornation of bicarbonate (eqs. 16-20). The synthesis of organlc compounds in dilute aqueous solutions of bicarbonate $\left(\mathrm{O}_{2}\right.$-free) is due to the reaction of the hydrated electron (eq. 8) with carbon dioxide which is present in the equilibrium with $\mathrm{HCO}_{3}^{-}$, and the subsequent reactions of carboxyl radical-ions (eqs. 13-16).

\section{ACKNOWLEDGEMENT}

The authors thank Hanne Corfitzen and Torben Johansen for technical assistance and are indebted to Erling Bjergbakke for computations and discussious. 

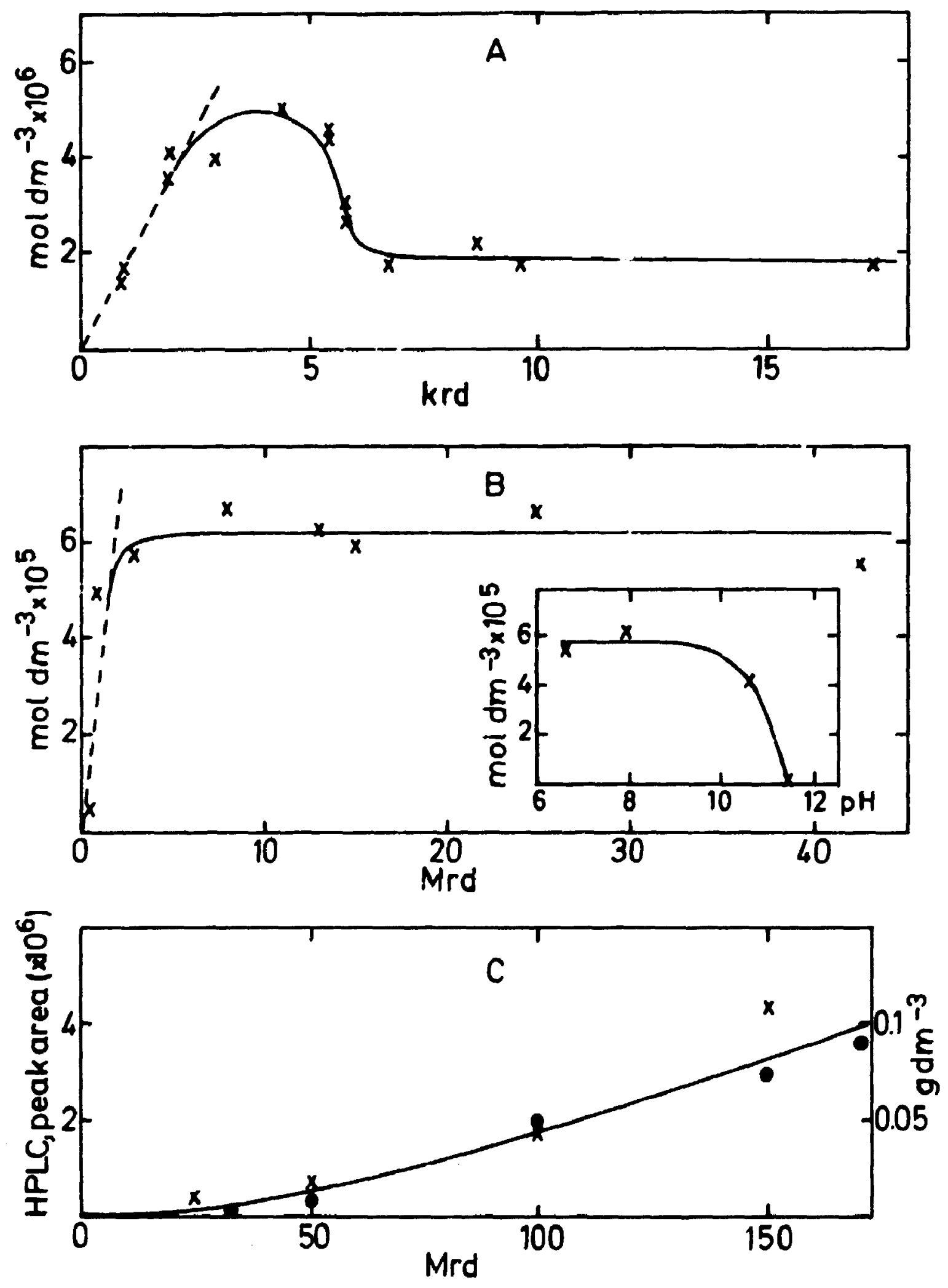
LEGEND

\section{Figure 1.}

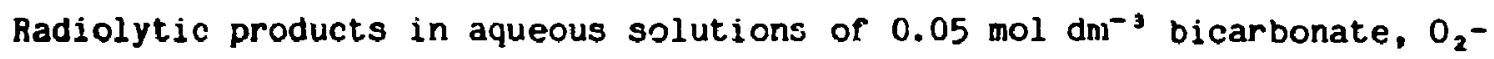
free: A.- Eormate, $G^{\circ}=2.2$; B. - Oxalate, $G^{\circ}=0.05$,

Insert: pH influence on the oxalate consentration measured at $13 \mathrm{Mrd}$;

C.- Polymeric material, $M_{W} 14000-16000$ daltons: the mass, $g \mathrm{dm}^{-3}(x)$; the peak area $\left(\times 10^{6}\right)$ in HPLC analysis $(\bullet)$. The dotted lines show the initial trend computed by using CHEMSIMUL and the reactions $(1 ;-(23)$. 
REFERENCES

1. T. Hasselstrom and M.C. Henry, Science, 1956, 123, 1038-1039.

2. I.S. Kolomnikov, T.V. Lysyak, E.A. Konash, E.P. Kalyazin, A.V. Rudev, and Yu. Ya. Kharitonov, Dokl. Akad. Nauk SSSR Phys Chem. 1982, 265. 596-597.

3. R. Paschke, R.W.H. Chang, and D. Young, Science 1957, 125, 881.

4. G.E. Adams, J.W. Boag, and B.D. Michael, Trans. Faraday Soc., 1965, 61, 1674-1680.

5. J.L. Weeks and J. Rabari, J. Phys. Chem. 1966, 70, 2100-2105.

6. J. Holcman. E. Bjergbakke and K. Sehested, The importance of radicalradical reactions in pulse radiolysis of aqueous carbonate/bicarbonate. 6 th Tihany Symp. on Radiation Chemistry, Hungary, 21-26 Sep. 1986 (to be published).

7. Z.D. Draganic, I.G. DraganiE, J.A. Azamar, S.I. VujoseviE, M.D. Berber, and A. Negrón-Mendoza, J. Mol. Evol. 1985, in press.

8. Z.D. Draganic. S.I. Vujosevie, A. Negrón-Mendoza, J.h. Azamar, and I.G. Draganic, J. Mol. Evol. 1985. in press.

9. A. Negrón-Mendoza, Z.D. Draganic, R. Navarro-Gonzales, and I.G. Draganic, Radiat. Res. 1983, 95, 284-261.

10. 0 . Lang Rasmussen and E. Bjergbakke, CHEMSIMUL - A Program Package for Numerical Simulation of Chemical Reaction Systems. Riso-R-395, 1984.

11. Fartahaziz and A.B. Ross, Selected specific rates of reactions of transients from water in aqueous solution - III. Hydroxyl radical and perhydroxyl radical and their radical ions. NSRDS-NBS 59, 1977.

12. M. Anbar, M. Bambenek, and A.B. Ross, Selected specific rates of reactions of transients from water in aqueous solution. I. Hydrated electron. NSRDS-NBS 43, 1973.

13. 2.D. Draganic and I.G. Draganie, J. Phys. Chem. 1973, 77, 765-772.

14. Gmelins Handbuch der Anorganischen Chemie, Ammonium. No. 23, VIII Auflage p. 354, Verlag Chemie GmbH, Weinheim 1955.

15. G. Buxton and W.K. Wilmarth, J. Phys. Chem. 1963, 67, 2835-2841.

16. A.B. Ross and P. Neta, Rate constants for reactions of aliphatic carbon-centered radicals in aqueous solution. NSRDS-NBS 70, 1982.

17. J. Lilie, R.J. Hanrahan, and A. Menglein, Rad. Phys. Chem. 1978, 11, 225-227.

18. P.B. Pagsberg, Risø-R-256, P. 209, 1972., Risø National Laboratory, Roskilde, Denmark. 
Z.D. Draganic*, I.G. Oraganić*, A. Negrón-Mendoza**, Date December 1986

K. Sehested, R. Navarro-Gonźales**, M.G. AiharránSánchez**

* Boris Kidrić Institute of Nuclear Sciences, P.0. Box 522, 11001 Belgrad, Yugoslaviá.

**Centro de Estudios Nucleares, Universidad Nacional Autonoma de Mexico, A. Postal 70-543, 04510 Mexico, D.F., Mexico.

\begin{tabular}{|c|c|c|c|c|}
\hline Poove 16 & Tables & Ilhustrations 1 & Peferences & ISBN $87-550-1288-4$ \\
\hline
\end{tabular}

Abstract (max. 2000 char.)

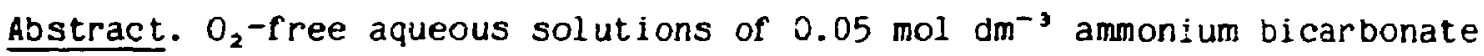
were studied after receiving various doses of ${ }^{60} \mathrm{Co}$ gammas (0.001-170 Mrd) or krd pulses of $10 \mathrm{MeV}$ electrons. Formate, oxalate, formaldehyde and an unidentified polymer ( $M_{W} 14000-16000$ daltons) were found to be the main radiolytic products. A large initial yield of formate in the r-radiolysis, $\mathrm{G}\left(\mathrm{HCOO}^{-}\right)=$ 2.2 , is due to the reaction $\mathrm{CO}_{2}^{-}+\mathrm{HCO}_{3}^{-}+\mathrm{HCOO}^{-}+\mathrm{CO}_{3}^{-}$. The efficiency of organic synthesis within the large dose range studied is low and is explained by efficient pathways to the reformation of bicarbonate, where the reaction $\mathrm{CO}_{2}^{-}+\mathrm{CO}_{3}^{-}$is particularly significant. Computer fitting of the data obtained in the $\gamma$-radiolysis and by pulsed electron beam experiments gives $\mathrm{k}_{\left(\mathrm{CO}_{2}^{-}\right.}+$ $\left.\mathrm{HCO}_{3}^{-}\right)=(2 \pm 0.4) \times 10^{3} \mathrm{dm}^{3} \mathrm{mcl}^{-1} \mathrm{~s}^{-1}, \mathrm{k}\left(\mathrm{CO}_{2}^{-}+\mathrm{CO}_{3}^{-}\right)=\left(5 \pm 1 ; \times 10^{7} \mathrm{dm}^{3} \mathrm{~mol}^{-1} \mathrm{~s}^{-1}\right.$, $\mathrm{k}\left(\mathrm{NH}_{2}+\mathrm{HCO}_{3}^{-}\right)<10^{4} \mathrm{dm}^{3} \mathrm{~mol}^{-1} \mathrm{~s}^{-1}$ and $\mathrm{k}\left(\mathrm{NH}_{2}+\mathrm{CO}_{3}^{-}\right)=(1.5 \pm 0.5) \times 10^{9}$ $\mathrm{dm}^{3} \mathrm{~mol}^{-1} \mathrm{~s}^{-1}$.

Descriptors - INIS

ACID CARBONATES; AMMONIA; AMMONIUM CARBONATES; AQUEOUS SOLUTIONS; CARBAMATES; COMPUTERIZED SIMULATION; GAMMA RADIATION; PULSED IRRADIATION; RADIOLYSIS 
Available on request from.

Rise Library,

Rise National Laboratory, P. O. Box 49,

DK-4000 Roskilde, Denmark

ISBN 87-550-1 288-4

Phone (02) 371212 ext.2262

ISSN 0418.6435 